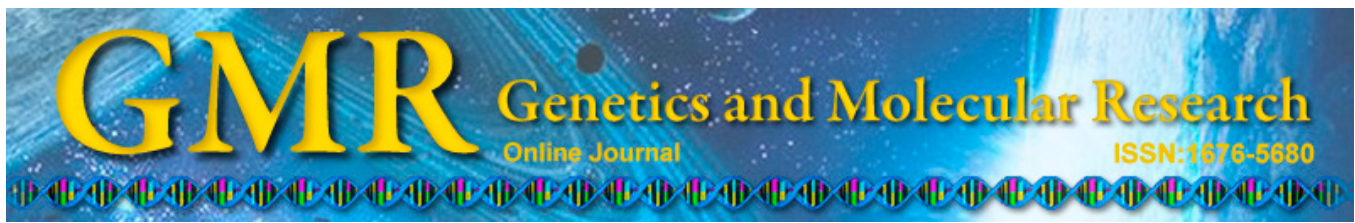

\title{
Evaluation of a modified sampling method for molecular analysis of air microflora
}

\author{
T. Lech $^{1}$ and A. Ziembinska-Buczynska ${ }^{2}$ \\ ${ }^{1}$ Department of Microbiology, Faculty of Commodity Science, \\ Cracow University of Economics, Rakowicka, Krakow, Poland \\ ${ }^{2}$ Department of Environmental Biotechnology, \\ Faculty of Power and Environmental Engineering, \\ The Silesian University of Technology, Akademicka, Gliwice, Poland \\ Corresponding author: T. Lech \\ E-mail: lecht@uek.krakow.pl
}

Genet. Mol. Res. 14 (2): 3200-3208 (2015)

Received May 28, 2014

Accepted September 22, 2014

Published April 10, 2015

DOI http://dx.doi.org/10.4238/2015.April.10.32

\begin{abstract}
A serious issue concerning the durability of economically important materials for humans related to cultural heritage is the process of biodeterioration. As a result of this phenomenon, priceless works of art, documents, and old prints have undergone a process of decomposition caused by microorganisms. Therefore, it is important to constantly monitor the presence and diversity of microorganisms in exposition rooms and storage areas of historical objects. In addition, the use of molecular biology tools for conservation studies will enable detailed research as well as reduce the time needed to perform the analyses compared with using conventional methods related to microbiology and conservation. The aim of this study was to adapt the sampling indoor air method for direct DNA extraction from microorganisms, including evaluating the extracted DNA quality and concentration. The obtained DNA was used to study the diversity of mold fungi in indoor air using polymerase chain reaction-denaturing gradient gel electrophoresis in specific archives and museum environments. The research was conducted in 2 storage rooms of the National Archives
\end{abstract}


in Krakow and in 1 exposition room of the Archaeological Museum in Krakow (Poland).

Key words: DNA extraction; Indoor air quality; Microbial biodiversity; PCR-DGGE

\section{INTRODUCTION}

Over the course of centuries, all materials created by humans undergo biodeterioration, which is the process of microbiological destruction. This includes cultural heritage objects such as documents, old prints, and other written documents, which are currently of value from both economic and historical perspectives (Konkol et al., 2010). Microbiological decomposition occurs largely as a result of the enzymatic activities of microorganisms that are able to break down organic compounds (such as cellulose, keratin, fibroin, and collagen), which represent the principal structural element of modern and historical materials, including paper, fabrics, parchment, and leather. As a result of this activity, physicochemical changes weaken the material structure, which is manifested as crumbling, decreased durability, fading, and discoloration, which over a longer period of time leads to complete destruction (Szostak-Kot and Sygula-Cholewinska, 2012; Gutarowska et al., 2012). Mold fungi and Actinobacteria play a crucial role in deterioration of museum objects. They do not require such a high humidity and temperatures as the bacteria and adapt to new environmental conditions very quickly (Zyska, 1997; Camuffo et al., 1999, 2001; Gysels et al., 2004; Nunes et al., 2013). The diversity of fungi in indoor air depends on environmental conditions such as humidity and temperature, as well as on the nature of the stored materials (paper, leather, parchment) (Mesquita et al., 2009). Other important factors affecting changes in the diversity and quantity of microorganisms in historical object storage and exposition areas are both the number of people coming into the room and the frequency of their visits (Gaüzère et al., 2013). To monitor changes in microbial diversity, polymerase chain reaction-denaturing gradient gel electrophoresis (PCRDGGE) can be used, through which the fingerprint of a particular environment, and in this case the storage area, can be prepared. The DGGE technique was successfully applied in previous studies of historical object and artwork microbial diversity (Schabereiter-Gurtner et al., 2001; Michalsen et al., 2006; Principi et al., 2011, Kraková et al., 2012). A key step in studying diversity using this method appears to be the appropriate sampling and preparation of genetic material. Sampling difficulties, particularly those concerning indoor air sampling, may occur because of the low concentration of microorganisms (Tringe et al., 2008), which may require the use of efficient air sampling devices. In this study, we developed a simple method of air sampling using the air sampler and cellulose membranes on which microorganisms were collected and then isolated the DNA. Next, fingerprints were generated using the DGGE technique for different storage and exposition areas of historical objects. This PCR-based technique is widely used for microbial monitoring because it produces repeatable and fast results. In addition, only a small amount of DNA sample is required for PCR to determine the complexity of an entire community. Studies examining microorganisms present in the indoor air of museums, archives, or libraries is primarily based on cultivation methods using microbiological media suitable for the development of bacteria and fungi (Jo and Seo, 2005; Chen et al., 2010; Mendes et al., 2013); therefore, available molecular techniques can be adjusted and implemented for these studies. 


\section{MATERIAL AND METHODS}

Air samples were collected in 2 rooms in which historic objects are stored at the National Archives in Krakow, Poland. The first storage room (sample 1) holds various archival materials made of paper, leather, and parchment, among others, with the collections dating from the 13th century. The second room (sample 2) primarily holds paper documents from the 19th and 20th centuries. The next 2 samples of air were from the Archaeological Museum in Krakow, Poland. The samples were from the one exposition room of Peruvian ceramics collection during different seasons of the year (spring: sample 3; summer: sample 4).

\section{Air samples collection}

A modified method of collecting environmental air samples used for the analysis of microbiological diversity was developed. Genetic material for analysis can be obtained while omitting the laboratory cultivation stage. Air samples were collected using an impact method with an air-sampler (MAS-100Eco, MBV AG, Stäfa, Sweden). A Petri dish with a sterile cellulose membrane was placed in the air probe (Milipore, Billerica, MA, USA). The membrane was moistened with $1 \mathrm{~mL}$ sterile water (Sigma-Aldrich, St. Louis, MO, USA) and then aspirated with 3500-5000 L air; after every $500 \mathrm{~L}$ air, the membrane was moistened with 300-500 $\mu \mathrm{L}$ water. The membrane was then placed in a sterile flask containing glass beads that were 3-4 $\mathrm{mm}$ in diameter and $4 \mathrm{~mL}$ sterile water was added. The membrane was shaken for $5 \mathrm{~min}$. Following extraction, the liquid was gradually placed in a $1.5-\mathrm{mL}$ tube and centrifuged after each addition for $2 \mathrm{~min}$ at $13,000 \mathrm{~g}$; the supernatant was removed and the sediment and a slight amount of liquid $(\sim 50-100 \mu \mathrm{L})$ were retained. DNA was isolated from approximately 100-150 $\mu \mathrm{L}$ liquid and centrifuged sediment.

\section{DNA extraction}

For DNA isolation, the standard multi-phased phenol-chloroform method proposed by Byrd et al. (1990) was used with modifications. The phenol-chloroform method provides satisfactory recovery of DNA from environments such as indoor air, which contain low DNA concentration (Lech et al., 2014). Prepared samples collected from the air were flooded with $400 \mu \mathrm{L}$ optimized lysis buffer (100 mM EDTA; $100 \mathrm{mM}$ Tris- $\mathrm{HCl}, \mathrm{pH} 8,0.5 \mathrm{M} \mathrm{NaCl} ; 3 \%$ sodium dodecyl sulfate) with the addition of lyticase enzyme ( $400 \mathrm{U} /$ sample). After mixing, the samples were incubated in a thermoblock for approximately $16 \mathrm{~h}$ at $55^{\circ} \mathrm{C}$, with shaking at $550 \mathrm{rpm}$ (Biometra, Goettingen, Germany). Proteinase $\mathrm{K}$ was then added at a concentration of $1 \mathrm{mg} / \mathrm{mL}$ and the samples were incubated for $1 \mathrm{~h}$ under the same conditions. Next, $500 \mu \mathrm{L}$ phenol was added to the samples, which were mixed carefully by inversion $(25 \mathrm{X})$. The samples were centrifuged at $9500 \mathrm{~g}$ for $10 \mathrm{~min}$ at room temperature. The upper water phase was moved to new tubes, and then $500 \mu \mathrm{L}$ phenol-chloroform at a 1:1 ratio was added and mixed by inversion (20X). After centrifuging at $9500 \mathrm{~g}$ for $10 \mathrm{~min}$ at room temperature, the upper phase was again moved to new sterile tubes, while avoiding disturbing the phase borders. DNA was precipitated by adding $500 \mu \mathrm{L}$ isopropanol to each sample. The DNA was pelleted by centrifugation for $1 \mathrm{~min}$ at 13,000 $\mathrm{g}$ at room temperature and washed with $200 \mu \mathrm{L} 70 \%$ ethanol for 10 min. After centrifugation for $1 \mathrm{~min}$ at 13,000 $\mathrm{g}$ at room temperature and removing ethanol, the DNA was suspended in $60 \mu \mathrm{L}$ water or Tris-EDTA buffer. 


\section{Spectrophotometric analysis}

Quantitative and qualitative analysis of the obtained DNA was carried out using a nano-spectrophotometer (IMPLEN, München, Germany). The purity of DNA was also analyzed by analyzing the $\mathrm{A}_{260} / \mathrm{A}_{280}$ and $\mathrm{A}_{260} / \mathrm{A}_{230}$ ratios.

\section{PCR amplification of extracted DNA}

For DGGE analysis, the internal transcribed spacer 1 (ITS1) region was selected, which is the fragment of ribosomal DNA (rDNA) ITS, and nested PCR procedure was applied to obtain amplicons. All PCRs were conducted in a Thermal Cycler T100 (Bio-Rad, Hercules, CA, USA). In the first stage, the following primers were used: ITS1F (5'-CTTGGTCATTTAG AGGAAGTAA-3') and ITS4 (5'-TCCTCCGCTTATTGATATGC-3'), which have been previously described by Manter and Vivanco (2007), White et al. (1990), and Gardes and Bruns (1993). PCR was conducted in a volume of $30 \mu \mathrm{L}$ and contained the following: $21.9 \mu \mathrm{L}$ water (double-processed tissue culture water, Sigma-Aldrich), $3 \mu \mathrm{L}$ 10X concentrated buffer (Invitrogen), $1.5 \mu \mathrm{L} \mathrm{MgCl}_{2}$ (50 mM; Invitrogen); $0.6 \mu \mathrm{L}$ of each forward and reverse primers (10 $\mu \mathrm{M}$; Genomed, Warsaw, Poland), $0.9 \mu \mathrm{L}$ dNTP (10 mM; Sigma-Aldrich), $0.5 \mu \mathrm{L}$ Taq polymerase $(2 \mathrm{U} / \mu \mathrm{L}$; Bio-Rad), and $1.0 \mu \mathrm{L}$ genomic DNA. The reaction was conducted following the method of Hou et al. (2013): DNA predenaturation at $94^{\circ} \mathrm{C}$ for $5 \mathrm{~min} ; 20$ cycles consisting of DNA denaturation at $94^{\circ} \mathrm{C}$ for $45 \mathrm{~s}$, annealing at the temperature of $68-58^{\circ} \mathrm{C}$ for $180 \mathrm{~s}$ (lowering the temperature by $0.5^{\circ} \mathrm{C}$ for each cycle), synthesis of new complementary chain for $60 \mathrm{~s}$ at $72^{\circ} \mathrm{C}$; and then 10 cycles of DNA denaturation at $94^{\circ} \mathrm{C}$ for $45 \mathrm{~s}$, annealing the primers to the matrix at $58^{\circ} \mathrm{C}$ for $180 \mathrm{~s}$; complementary strand synthesis for $60 \mathrm{~s}$ at $72^{\circ} \mathrm{C}$, and a final elongation for $5 \mathrm{~min}$ at $72^{\circ} \mathrm{C}$. The amplified products were used as a matrix for subsequent PCR, which was conducted using the following primers: ITS1F-GC (5' CGCCCGCCGGCGGCGGCGG GCGGGGCGGGGGCACGGGGGGCTTGGTCATTTAGAGGAAGTAA-3') as well as ITS2 (5'-GCTGCGTTCTTCATCGATGC-3'). The 30- $\mu$ L reaction consisted of the following: 12.4 $\mu \mathrm{L}$ water (double-processed tissue culture water; Sigma-Aldrich); $3 \mu \mathrm{L} 10 \mathrm{X}$ concentrated buffer (Invitrogen); $2 \mu \mathrm{L} \mathrm{MgCl}_{2}(50 \mathrm{mM}$; Invitrogen); $0.6 \mu \mathrm{L}$ of each forward and reverse primer (10 $\mu \mathrm{M}$; Genomed); $0.8 \mu \mathrm{L}$ dNTPs (10 mM; Sigma-Aldrich); $0.6 \mu \mathrm{L}$ Taq polymerase (2 U/ $\mu \mathrm{L}$; Bio-Rad), and $10 \mu \mathrm{L}$ of the previous PCR. The reaction was conducted under the same conditions as the first reaction.

\section{Gel analysis}

To evaluate the nested PCR products, agarose gel electrophoresis was conducted. First, $0.5 \mu \mathrm{L} 10 \mathrm{X}$ concentrated loading buffer (BlueJuice, Invitrogen) was added to $5 \mu \mathrm{L}$ of each sample of extracted DNA. Next, the samples were run on a $1.8 \%$ agarose gel containing $0.1 \mu \mathrm{g} / \mathrm{mL}$ ethidium bromide. The results were visualized using an ultraviolet system to archive the electrophoretic gels (PolyGen, Edgewood, NY, USA).

\section{DGGE separation and results}

The PCR amplicons for fungi with GC clamp were separated on an $8 \%$ polyacrylamide gel (acrylamide:bisacrylamide, 39.5:1) containing 30-60\% denaturant (urea). Electrophoretic 
separation was performed in $1 \mathrm{X}$ TAE buffer (Tris, acetic acid, EDTA, pH 8.0) in a DCode Mutation Detection System (Bio-Rad). The electrophoresis was run for $17 \mathrm{~h}$ at $40 \mathrm{~V}$ and $60^{\circ} \mathrm{C}$. The gel was stained with SYBR Green (1:10,000; Invitrogen) for 15 min and destained in MilliQ water for $30 \mathrm{~min}$. The gel was visualized under UV light and photographed. Densitometric analysis was performed using Quantity One 1-D software (Bio-Rad). The Shannon biodiversity index was calculated as described previously (Ziembińska et al., 2009).

\section{RESULTS}

In this study, we propose the use of an impact method involving an air probe and wet cellulose membranes. Using this technique, we obtained a suitable amount of microbiological material to conduct direct isolation of DNA from an environmental sample; however, a $3500-5000 \mathrm{dm}^{3}$ volume of air was needed. The quality of the genetic material isolated was evaluated electrophoretically (Figure 1) as well as measured spectrophotometrically (Table 1). The results of the study indicate that the technique was effective for obtaining air samples for direct isolation of DNA.

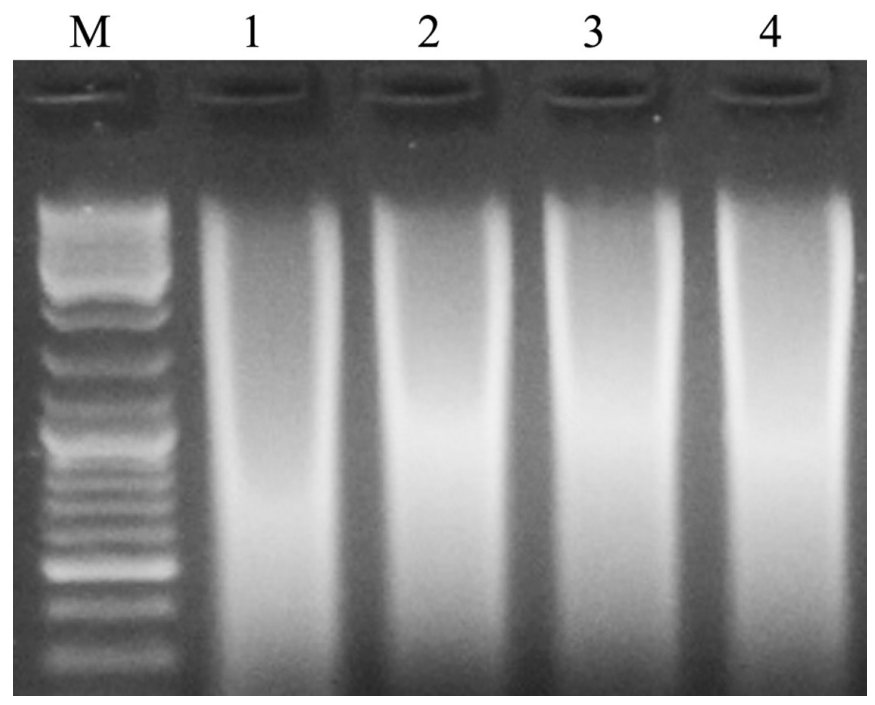

Figure 1. Agarose gel electrophoresis of extracted DNA. Lane $M=$ DNA marker (O'Gene Ruler DNA Ladder Mix); lanes 1 and 2 = samples from the National Archives in Krakow; lanes 3 and $4=$ samples from the Archaeological Museum in Krakow.

Table 1. Concentrations and purity of obtained DNA.

\begin{tabular}{|c|c|c|c|}
\hline Sample & Concentration (ng/L) & $\mathrm{A}_{260} / \mathrm{A}_{280}$ & $\mathrm{~A}_{260} / \mathrm{A}_{230}$ \\
\hline 1 & 155.9 & 1.81 & 1.78 \\
\hline 2 & 187.2 & 1.91 & 1.82 \\
\hline 3 & 195.7 & 1.98 & 1.88 \\
\hline 4 & 189.4 & 1.89 & 1.84 \\
\hline
\end{tabular}


To further verify the quality and functionality of the extracted genetic material, we analyzed fungal diversity present in the environment using DGGE. Amplicons of approximately $300 \mathrm{bp}$ were obtained using nested PCR with the standard primers ITS1F and ITS4 in the first PCR and ITSF-GC and ITS2 in the second PCR (Figure 2).

Obtained PCR products were separated by polyacrylamide electrophoresis with an increasing denaturant concentration gradient, resulting in a characteristic fingerprint for each environment (Figure 3). The fingerprints obtained by DGGE separation showed high-quality PCR products, and thus good quality of extracted DNA. DGGE separation allowed for the qualitative analysis of the fungal community as well as determination of the biodiversity level in the studied sample by calculating the index of biodiversity. The Shannon index was applied, which is the most common biodiversity index used in microorganism ecology studies (Ziembińska et al., 2009). This index indicates the level of diversity of microorganism genotypes present in an examined sample. According to the conducted analysis, samples 1 and 4 showed the highest and comparable levels of genotype diversity, whereas sample 2 showed the lowest biodiversity. This dependence is related to the absence of the genotype with a relatively low number of GC pairs in sample 2 (Figure 3, upper part of the gel). In the remaining samples, these genotypes appeared to be dominant in biocenosis.

The sample profiles were diverse in terms of quality; in samples 1 and 2, the dominant genotypes showed GC pair content, in samples 3 and 4, the number of genotypes rich and poor in GC pairs was comparable. According to the biodiversity calculation (Figure 4), the diversity was directly related to the material type in the museum storage room or with environmental conditions in a particular location. Sample 1 was collected from the storage room containing material and age-diverse objects. These materials may be colonized by a wider range of microorganisms (more diverse community) compared to the paper items. That may explain why sample 1 showed higher biodiversity than sample 2. In samples 3 and 4, higher biodiversity was observed for sample 4, which was collected during a more humid and vegetative period. Air sample 3 contained mostly fungal spores, which may explain why it was resistant to the DNA isolation procedure, as the fungal wall is stronger than that on vegetative fungal cells. The spores may sporulate at higher humidity levels, and thus the higher biodiversity may be linked with the presence of vegetative cells.

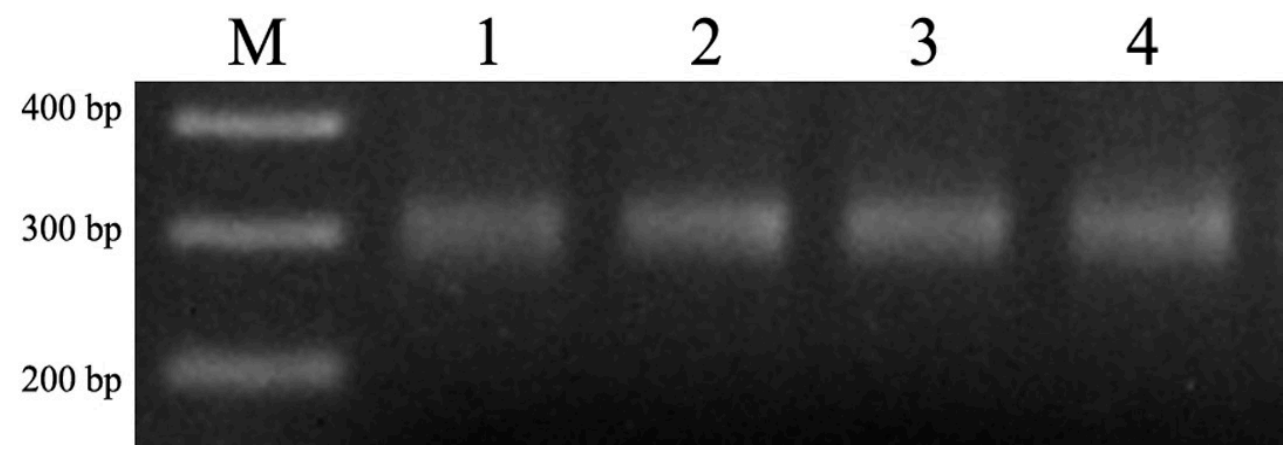

Figure 2. Electrophoresis of PCR products. Lane $M=$ DNA marker (O'GeneRulerDNALadder Mix); lanes 1 and 2 samples from the National Archives in Krakow, lanes 3 and $4=$ samples from the Archaeological Museum in Krakow. 


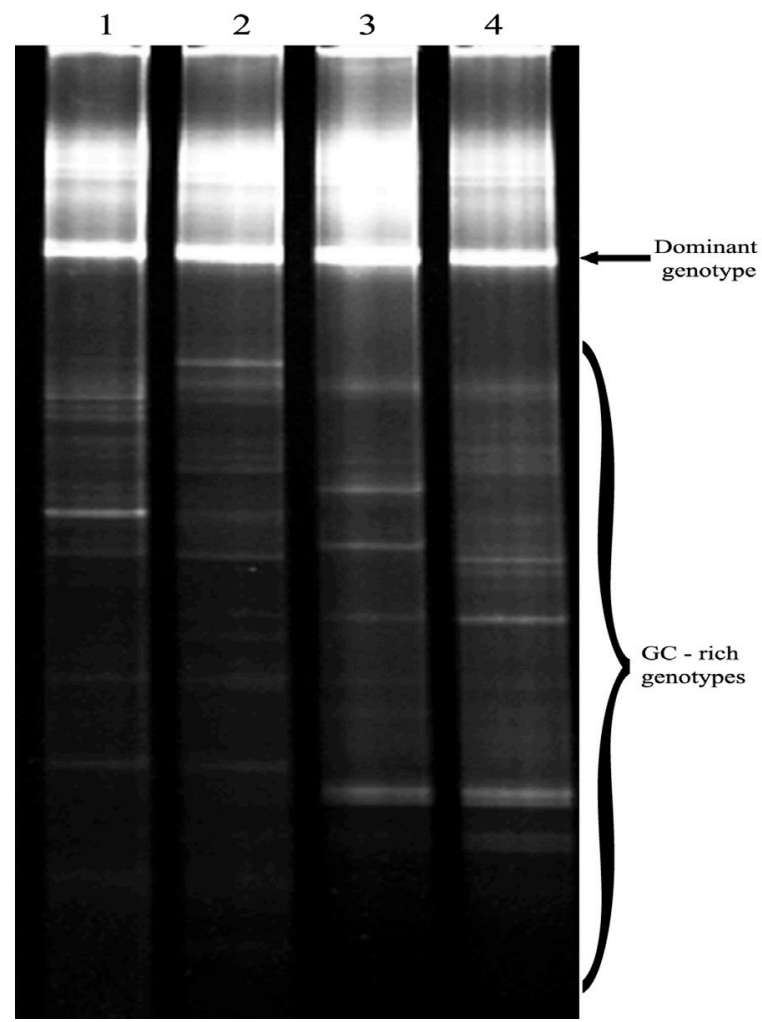

Figure 3. Electrophoresis of PCR-DGGE (fingerprint). Lanes 1 and $2=$ samples from the National Archives in Krakow; lanes 3 and 4 = samples from the Archaeological Museum in Krakow.

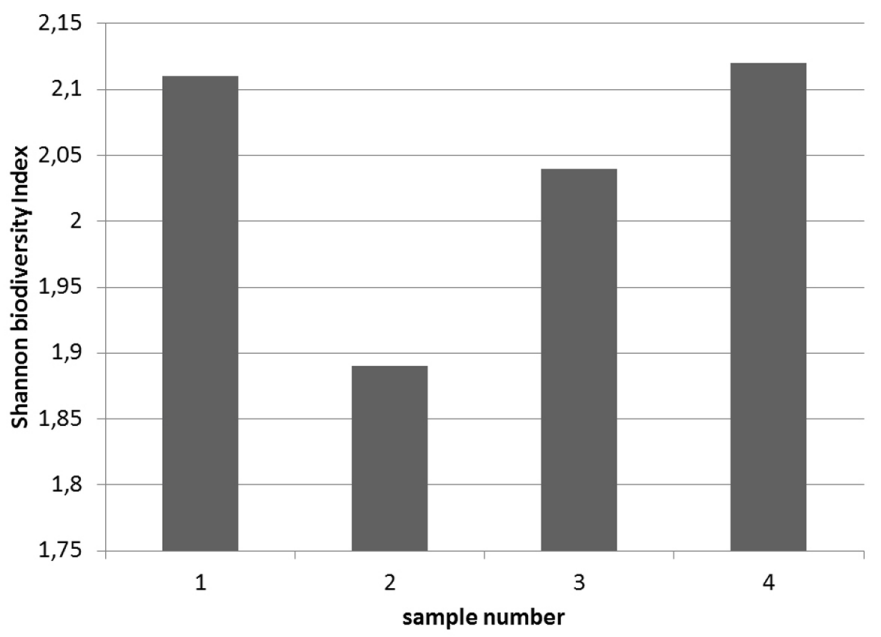

Figure 4. Shannon biodiversity index calculated based on densitometric analysis from DGGE fingerprints. 1 and 2 $=$ samples from the National Archives in Krakow; 3 and $4=$ samples from the Archaeological Museum in Krakow. 


\section{DISCUSSION}

Microorganisms, particularly fungi and Actinobacteria, are highly destructive to certain materials, and thus may play a primary role in the biodeterioration of archival materials (Sterflinger, 2010). The presence of fungi, as well as the mycotoxins that they produce, in spaces where historical objects are stored, restored, and in exhibit halls can be dangerous for both museum workers and visitors (Chen et al., 2010; Pasquarella et al., 2012). Previous analyses of indoor air in museums and archives have largely been based on classical methods such as sedimentation or impact aspiration of air samples on properly selected microbiological media. An imperfection of these methods, although they are still adequate, is the low percentage of microorganisms cultivated under laboratory conditions. The most important limitation of molecular methods used for detailed characterization of the air microflora is collecting air samples. Scientists have long sought a suitable method for obtaining air samples, and these efforts have increased with the availability of more advanced methods for the analysis of microorganisms. To date, techniques for obtaining samples, from simple-sedimentation methods, impact or filtering, have been used in various studies (Stetzenbach et al., 2004). The use of the proposed procedure for air sampling, DNA extraction, and further analysis of diversity with the DGGE technique may be successful for routine control of microbiological quality of indoor environment, including storage and exhibition areas where historic objects are stored. To maintain an adequate level of indoor air quality, further studies are needed to determine the diversity and quantity of microorganisms and their fluctuations in a variety of urban indoor environments (Gaüzère et al., 2013).

\section{REFERENCES}

Byrd AD, Schardl CL, Songlin PJ, Mogen KL, et al. (1990). The beta-tubulin gene of Epichloë typhina from perennial ryegrass (Lolium perenne). Curr. Genet. 18: 347-354.

Camuffo D, Brimblecombe P, Grieken RV, Busse HJ, et al. (1999). Indoor air quality at the Correr Museum, Venice, Italy. Sci. Total Environ. 236: 135-152.

Camuffo D, Grieken RV, Busse H, Sturaro G, et al. (2001). Environmental monitoring in four European museums. Atmospheric Environ. 35: 127-140.

Chen YP, Cui Y and Dong JG (2010). Variation of airborne bacteria and fungi at Emperor Qin's Terra-Cotta Museum, Xi'an, China, during the “Oct. 1" gold week period of 2006. Environ. Sci. Pollut. Res. Int. 17: 478-485.

Gardes M and Bruns TD (1993). ITS primers with enhanced specificity for basidiomycetes - application to the identification of mycorrhizae and rusts. Mol. Ecol. 2: 113-118.

Gaüzère C, Moletta-Denat M, Blanquart H, Ferreira S, et al. (2013). Stability of airborne microbes in the Louvre Museum over time. Indoor Air 24: 29-40.

Gutarowska B, Skora J, Zduniak K and Rembisz D (2012). Analysis of the sensitivity of microorganisms contaminating museums and archives to silver nanoparticles. Int. Biodeter. Biodegr. 68: 7-17.

Gysels K, Delalieux F, Deutsch F, Grieken RV, et al. (2004). Indoor environment and conservation in the Royal Museum of Fine Arts, Antwerp, Belgium. J. Cult. Herit. 5: 221-230.

Hou JM, Ma BC, Zuo YH, Guo LL, et al. (2013). Rapid and sensitive detection of Curvularia lunata associated with maize leaf spot based on its Clg2p gene using semi-nested PCR. Lett. Appl. Microbiol. 56: 245-250.

Jo WK and Seo YJ (2005). Indoor and outdoor bioaerosol levels at recreation facilities, elementary schools, and homes. Chemosphere 61: 1570-1579.

Konkol N, McNamara ChJ and Mitchell R (2010). Fluorometric detection and estimation of fungal biomass on cultural heritage materials. J. Microbiol Methods. 80: 178-182.

Kraková L, Chovanová K, Selim SA, Šimonovičová A, et al. (2012). A multiphasic approach for investigation of the microbial diversity and its biodegradative abilities in historical paper and parchment documents. Int. Biodeter. Biodegr. 70: 117-125. 
Lech T, Sygula-Cholewinska J and Szostak-Kot J (2014). An economical and combined method for rapid and efficient isolation of fungal DNA. Genet. Mol. Res. 13: 10779-10786.

Manter DK and Vivanco JM (2007). Use of the ITS primers, ITS1F and ITS4, to characterize fungal abundance and diversity in mixed-template samples by qPCR and length heterogeneity analysis. J. Microbiol. Methods 71: 7-14.

Mendes A, Pereira C, Mendes D, Aguiar L, et al. (2013). Indoor air quality and thermal comfort - results of a pilot study in elderly care centers in Portugal. J. Toxicol. Environ. Health 76: 333-344.

Mesquita N, Portugal A, Videira S, Rodríguez-Echeverría S, et al. (2009). Fungal diversity in ancient documents. A case study on the Archive of the University of Coimbra. Int. Biodeter. Biodegr. 63: 626-629.

Michalsen A, Pinzari F, Ripka K, Lubitz W, et al. (2006). Application of molecular techniques for identification of fungal communities colonising paper material. Int. Biodeter. Biodegr. 58: 133-141.

Nunes I, Mesquita N, Verde SC, Leitão-Bandeira AM, et al. (2013). Characterization of an airborne microbial community: A case study in the archive of the University of Coimbra, Portugal. Int. Biodeter. Biodegr. 79: 36-41.

Pasquarella C, Saccani E, Sansebastiano GE, Ugolotti M, et al. (2012). Proposal for a biological environmental monitoring approach to be used in libraries and archives. Ann. Agric. Environ. Med. 19: 209-212.

Principi P, Villa F, Sorlini C and Cappitelli F (2011). Molecular studies of microbial community structure on stained pages of Leonardo da Vinci's Atlantic Codex. Microb. Ecol. 61: 214-222

Schabereiter-Gurtner C, Piñar G, Lubitz W and Rölleke S (2001). An advanced molecular strategy to identify bacterial communities on art objects. J. Microbiol. Methods 45: 7-87.

Sterflinger K (2010). Fungi: Their role in deterioration of cultural heritage. Fungal Biol. Rev. 24: 47-55.

Stetzenbach LD, Buttner MP and Cruz P (2004). Detection and enumeration of airborne biocontaminants. Curr. Opin. Biotechnol. 15: 170-174.

Szostak-Kot J and Sygula-Cholewinska J (2012). Microbial risks for museum objects during storage. 18th IGWT - International Society of Commodity Science and Technology - Symposium "Technology and Innovation for a Sustainable Future: a Commodity Science Perspective”, September 24th-28th, 2012, Proceedings CD-ROM, ISBN 978-88-8286-269-5.

Tringe SG, Zhang T, Liu X, Yu Y, et al. (2008). The airborne metagenome in an indoor urban environment. PLoSOne 3: 1-10. White TJ, Bruns TD, Lee S and Taylor J (1990). Analysis of phylogenetic relationships by amplification and direct sequencing of ribosomal RNA genes. In: PCR Protocols: a Guide to Methods and Applications (Innis MA, Gelfand DH, Sninsky JJ and White TJ, eds.). Academic Press, New York, 315-322.

Ziembińska A, Ciesielski S and Miksch K (2009). Ammonia oxidizing bacteria community in activated sludge monitored by denaturing gradient gel electrophoresis (DGGE). J. Gen. Appl. Microbiol. 55: 373-380.

Zyska B (1997). Fungi isolated from library materials: a review of the literature. Int. Biodeter. Biodegr. 40: 43-51. 